\title{
Nursing performance in robotic surgeries: integrative review
}

\author{
Atuação da enfermagem em cirurgias robóticas: revisão integrativa \\ El desempeño de la enfermería en cirugías robóticas: una revisión integrativa
}

\section{Raísha Costa Martins' \\ ORCID: 0000-0001-6286-3571 \\ Denilse Damasceno Trevilato" \\ ORCID: 0000-0003-4050-568X \\ Marielli Trevisan Jost"I \\ ORCID: 0000-0002-9400-5149 \\ Rita Catalina Aquino Caregnato ${ }^{\text {v }}$ ORCID: 0000-0001-7929-7676}

'Universidade Federal de Ciências da Saúde de Porto Alegre (UFCSPA), graduação em Enfermagem.

Porto Alegre, Rio Grande do Sul, Brasil.

"Universidade Federal de Ciências da Saúde de Porto Alegre (UFCSPA), Programa de Pós-Graduação em Ensino na Saúde.

Porto Alegre, Rio Grande do Sul, Brasil.

I' Universidade Federal de Ciências da Saúde de Porto Alegre (UFCSPA), Programa de Pós-Graduação em Enfermagem.

Porto Alegre, Rio Grande do Sul, Brasil.

" Universidade Federal de Ciências da Saúde de Porto Alegre (UFCSPA), Departamento de Enfermagem.

Porto Alegre, Rio Grande do Sul, Brasil.

How to cite this article:

Martins RC, Trevilato DD, Jost MT, Caregnato RCA.

Nursing performance in robotic surgeries: integrative review. Rev Bras Enferm. 2019;72(3):795-800. doi: http://dx.doi.org/10.1590/0034-7167-2018-0426

Corresponding Author:

Denilse Damasceno Trevilato E-mail: denilse.trevilato@gmail.com

Submission: 06-08-2018 Approval: 02-10-2019

\begin{abstract}
Objective: To know the scientific production on the performance of the nursing staff in robotic surgeries, identifying the role of the nurse in the three perioperative periods. Methods: Integrative review, search in the databases National Library of Medicine, National Institutes of Health, Scientific Electronic Library Online and Biblioteca Virtual em Saúde, performed from June to September, 2017; 17 selected articles met the inclusion criteria. Results: Most articles were published in foreign journals in English, nine in the United States, classified with evidence level of 4 and 5. The role of nursing in the perioperative period was identified, related mainly to patient safety. The most mentioned perioperative period in the articles was the intraoperative, with greater concern in the positioning of the patient. Conclusion: The nursing performance and patient safety in robotic surgeries are similar to the ones in major surgeries, requiring from the patient a specific knowledge on the setting and preparation of the robot. Descriptors: Robotics; Perioperative Nursing; Surgical Procedures, Operative; Nurse's Role; Technological Development.
\end{abstract}

\section{RESUMO}

Objetivo: Conhecer a produção científica sobre a atuação da equipe de enfermagem em cirurgias robóticas, identificando-se papel do enfermeiro nos três períodos do perioperatório. Método: Revisão integrativa, busca nas bases de dados National Library of Medicine National Institutes of Health, Scientific Electronic Library Online e Biblioteca Virtual em Saúde, realizada entre julho a setembro de 2017; 17 artigos selecionados atendiam aos critérios de inclusão. Resultados: Predominaram artigos publicados em periódicos estrangeiros na língua inglesa, nove nos Estados Unidos, classificados com nível de evidência 4 e 5 . Identificou-se papel da enfermagem no período perioperatório relacionados principalmente à segurança do paciente. O período perioperatório mais citado nos artigos foi o intraoperatório, com preocupação maior no posicionamento do paciente. Conclusão: A atuação de enfermagem nas cirurgias robóticas é semelhante a ocorrida em cirurgias de grande porte e com a segurança do paciente, exigindo do enfermeiro conhecimento específico sobre configuração e preparação do robô.

Descritores: Robótica; Enfermagem Perioperatória; Procedimentos Cirúrgicos Operatórios; Papel do Profissional de Enfermagem; Desenvolvimento Tecnológico.

\section{RESUMEN}

Objetivo: Conocer la producción científica sobre el desempeño del personal de enfermería en cirugías robóticas, identificando el papel del enfermero en los tres períodos del perioperatorio. Método: Revisión integrativa, desde la búsqueda en las bases de datos National Library of Medicine National Institutes of Health, Scientific Electronic Library Online y Biblioteca Virtual en Salud, realizada entre julio y septiembre de 2017; en la cual se seleccionaron 17 artículos que atendían a los criterios de inclusión. Resultados: Los artículos publicados en periódicos extranjeros en el idioma inglés fueron los más predominantes, con nueve en Estados Unidos, siendo clasificados con nivel de evidencia 4 y 5 . Se identificó el papel de la enfermería en el período perioperatorio asociado principalmente a la seguridad del paciente. El período perioperatorio más citado en los artículos fue el intraoperatorio, con una mayor preocupación con el posicionamiento del paciente. Conclusión: El desempeño de la enfermería en las cirugías robóticas es similar a la ocurrida en cirugías de gran porte y con la seguridad del paciente, que exige del enfermero un conocimiento específico sobre la configuración y preparación del robot. Descriptores: Robótica; Enfermería Perioperatoria; Procedimientos Quirúrgicos Operativos; Papel del Profesional de enfermería; Desarrollo Tecnológico. 


\section{INTRODUCTION}

The Surgical Center (SC) is the sector of the hospital where anesthetic, surgical, diagnostic and therapeutic procedures are performed, which can be an emergency, urgent or elective. It is considered a critical area, since it is a high-risk environment for the transmission of infections, with complex and interdisciplinary working practices. This unit, with different invasive interventions and availability of various high-precision materials, needs qualified professionals to meet the patient's demands and to domain the technological diversity found ${ }^{(1)}$.

In this sector, the nurse performs activities with specific characteristics, being responsible for organizing and ensuring that the assistance provided to the patient during the perioperative period will be provided, promoting continuity in care and managing the sector $^{(2)}$. Perioperative is understood as the three stages experienced by the patient in relation to the surgical procedure, that is, preoperative (24 prior to the surgery), transoperative/intraoperative and immediate postoperative ( 24 hours after the surgery) ${ }^{(3)}$. This professional must ensure a safe practice, so that technological advances do no stay ahead of their essential characteristic, care ${ }^{(4)}$.

The use of technologies such as laparoscopy led to a continuous expansion from minimally invasive surgery to robotic surgery. Thus, perioperative nurses and other members of the surgical team need to be updated on new technologies and instrumentation, as well as on techniques and challenges involved in the use of these resources to ensure patient safety ${ }^{(5)}$. Robotic surgery is a new revolution of modern surgery, associating all the benefits of minimally invasive surgery with the advantage of image stability, combined with third dimension resource (3D), reduction of tremors in the surgeon's hand and the mobility of intracorporal instrumentation, especially in operative areas of more restricted spaces ${ }^{(6)}$.

Some studies demonstrate that robotic surgery offers advantages in comparison with laparoscopy, and they highlight smaller incisions and scars, less blood loss, decreased pain and medication use, faster recovery, reduced risk of infection and hospitalization, with possible discharge in the same day. The main disadvantage of this technology is the cost, which is too high ${ }^{(7-10)}$.

In the United States, robotic technology is well developed since the beginning of the $21^{\text {st }}$ century, and there are more than 1,300 surgical robots in the whole country, however, this number is smaller in Brazil, as this new technology only arrived in the country in $2008^{(11-12)}$.

The main publications on robotic surgeries are concentrated in the medical field with focus on surgical technique, and there is a lack of studies focused on nursing and its role in the treatment of the patient, who is subjected to surgery with this new technology. Because it is recent in Brazil, knowledge is growing and few studies show which is the role played by the nursing staff in robotic surgeries, however, they should be updated on their role in the face of new technologies ${ }^{(12-13)}$. Therefore, this justifies this research, with the purpose of deepening nursing knowledge on robotic surgeries.

\section{OBJECTIVE}

To know the scientific production on the performance of the nursing staff in robotic surgeries, identifying the role of the nurse in the three perioperative periods.

\section{METHODS}

This is an integrative review, developed in six stages ${ }^{(14)}$, namely: 1) identification of the topic and selection of the research question; 2) establishment of inclusion and exclusion criteria; 3 ) identification of pre-selected and selected studies; 4) evaluation of selected studies; 5) analysis and interpretation of results; and 6) presentation of the review/knowledge synthesis.

The choice of this topic was due to the fact that it is a relatively new field in Brazil for nursing practice. The question "what is the tole of nursing in robotic surgeries in the three perioperative periods?" emerged as research question.

Inclusion criteria, established to maintain consistency with the research question, were: publications from the last 10 years; articles written in Portuguese, English and Spanish; and approach of robotic surgeries in human models. Exclusion criteria were: articles that did not address nursing practice, at least in one of the perioperative periods.

The databases selected for the search were the US National Library of Medicine National Institutes of Health (PubMed), Biblioteca Virtual em Saúde (BVS) and Scientific Electronic Library Online (SciELO).

The selection of descriptors occurred in the Medical Subject Headings (MeSH): robotics, nurse and surgical procedure, using the Boolean operator "AND" between them. To pre-select the articles, the title and abstracts of the studies that resulted from this combination of descriptors were read, while the identification of selected studies was through reading the full text. The articles were collected was from June to September, 2017.

After the search in the databases and applying the filters (last 10 years and investigated languages), a total of sixty-four (64) articles were identified. Forty-seven (47) articles were excluded based on the exclusion criteria and duplicate articles, so the sample consisted of seventeen (17) articles, as shown in Table 1.

Then, the critical analysis of the studies was performed, with grouping of information and division in the perioperative periods, and it was possible to discuss the results.

The selected articles were assessed in relation to the degree of evidence according to New JBI Levels of Evidence $(2013)^{(15)}$. The results of the selected studies were analyzed and discussed, allowing the presentation of the pertinent characteristics of the content in question. To identify the articles, the nomenclature "A", referring to "article", was used, followed by Arabic numerals. From the ethical point of view, the copyrights of the analyzed studies were respected.

Table 1 - Data search process for article selection in the databases PubMed, BVS and SciELO with descriptors "robotics AND nurse AND surgical procedure", June to September, Porto Alegre, Rio Grande do Sul, Brazil, 2017

\begin{tabular}{ccccc}
\hline Database & $\begin{array}{c}\text { Found } \\
\text { articles }\end{array}$ & $\begin{array}{c}\text { Duplicate } \\
\text { articles }\end{array}$ & $\begin{array}{c}\text { Excluded } \\
\text { articles }\end{array}$ & $\begin{array}{c}\text { Selected } \\
\text { articles }\end{array}$ \\
\hline PubMed & 52 & - & 38 & 14 \\
BVS & 12 & 4 & 5 & 3 \\
SciELO & 0 & 0 & 0 & 0 \\
Total & 64 & 4 & 43 & 17 \\
\hline
\end{tabular}




\section{RESULTS}

All 17 selected articles were published in English in foreign journals. Of these, nine come from the United States (USA), two from France, one from Spain, one from the United Kingdom, one from Italy, one from Australia, one from China and one from South Korea. All studies were published from 2010, with a greater number of publications in the year of 2013.

In relation to the journals in which the articles were published: two articles were from the Journal of the Association of periOperative Registered Nurses (AORN Journal) and one in each of the following journals: Cirurgía Española; Journal of Robotic Surgery; The Journal of Urology; Surgical Endoscopy; Patient Safety in Surgery; Innovations: Technology and Techniques in Cardiothoracic and Vascular Surgery; Journal of Endourology; The International Journal of
Medical Robotics and Computer assisted Surgery; CIN: Computers, Informatics, Nursing; Journal of the Society of Laparoendscopic Surgeons (JSLS); British Journal of Urology (BJU International); Urology ; Urologic Nursing; European Journal of Oncology Nursing; and Journal of Clinical Nursing.

Regarding the study design: four case reports; two prospective studies, two retrospective descriptive studies; three literature reviews; five descriptive exploratory studies; and one comparative descriptive study. Therefore, according to the Levels of Evidence for Effectiveness (JBI, 2013) ${ }^{(15)}$ : one article was classified as level of evidence 3; nine with level of evidence 4; and seven with level 5.

Chart 1 shows the synthesis of the articles included in this integrative review.

Figure 1 shows the distribution and percentage or selected articles according to the continents.

Chart 1 - Profile characterization of the articles on nursing and robotic surgery published in journals from 2008-2017.

\begin{tabular}{|c|c|c|c|c|}
\hline Tittle & Year & Journal & Method & $\begin{array}{l}\text { Level of } \\
\text { evidence }\end{array}$ \\
\hline $\begin{array}{l}\text { (A1) Multidisciplinary development of robotic surgery in a } \\
\text { University Tertiary Hospital: organization and outcomes }\end{array}$ & 2010 & Cirurgía Española & Case report & N5 \\
\hline $\begin{array}{l}\text { (A2) Setting up robotic surgery in gynaecology: the } \\
\text { experience of the Strasbourg teaching hospital }\end{array}$ & 2011 & J Robotic Surg & Prospective & N4 \\
\hline (A3) Best Practices for Minimally Invasive Procedures & 2010 & AORN J & Literature review & N5 \\
\hline $\begin{array}{l}\text { (A4) Long-Term Experience and Outcomes of Robotic Assisted } \\
\text { Laparoscopic Pyeloplasty in Children and Young Adults }\end{array}$ & 2011 & J Urology & $\begin{array}{l}\text { Retrospective } \\
\text { Descriptive }\end{array}$ & N4 \\
\hline $\begin{array}{l}\text { (A5) How to successfully implement a robotic pediatric } \\
\text { surgery program: lessons learned after } 96 \text { procedures }\end{array}$ & 2013 & Surg Endosc & $\begin{array}{l}\text { Retrospective } \\
\text { Descriptive }\end{array}$ & N4 \\
\hline $\begin{array}{l}\text { (A6) The second "time-out": a surgical safety checklist for } \\
\text { lengthy robotic surgeries }\end{array}$ & 2013 & Patient Safety in Surgery & Literature review & N5 \\
\hline $\begin{array}{l}\text { (A7) Can the learning curve of totally endoscopic robotic } \\
\text { mitral valve repair be short-circuited? }\end{array}$ & 2014 & Innovations & Descriptive exploratory & N4 \\
\hline $\begin{array}{l}\text { (A8) The value of open conversion simulations during } \\
\text { robot-assisted radical prostatectomy: implications for } \\
\text { robotic training curricula }\end{array}$ & 2015 & Journal of Endourology & Descriptive exploratory & N4 \\
\hline $\begin{array}{l}\text { (A9) Robot-Assisted Thoracic Surgery (RATS): Perioperative } \\
\text { Nursing Professional Development Program }\end{array}$ & 2015 & AORN J & Case report & N5 \\
\hline $\begin{array}{l}\text { (A10) Application of a laser-guided docking system in } \\
\text { robot-assisted urologic surgery }\end{array}$ & 2015 & $\begin{array}{l}\text { Int J Med Robotics Comp Assist } \\
\text { Surg }\end{array}$ & Comparative descriptive & N3 \\
\hline $\begin{array}{l}\text { (A11) Perioperative nurses' work experience with robotic } \\
\text { surgery }\end{array}$ & 2016 & $\begin{array}{l}\text { CIN: Computers, Informatics, } \\
\text { Nursing }\end{array}$ & Case report & N5 \\
\hline $\begin{array}{l}\text { (A12) Quality of communication in robotic surgery and } \\
\text { surgical outcomes }\end{array}$ & 2016 & JSLS & Prospective & N4 \\
\hline $\begin{array}{l}\text { (A13) Ambulatory movements, team dynamics and } \\
\text { interactions during robot-assisted surgery }\end{array}$ & 2016 & BJUI & Descriptive exploratory & N4 \\
\hline $\begin{array}{l}\text { (A14) Improving teamwork: evaluating workload of } \\
\text { surgical team during robot-assisted surgery }\end{array}$ & 2017 & J Urology & Descriptive exploratory & N4 \\
\hline (A15) The bedside assistant in robotic surgery - keys to success & 2013 & Urologic Nursing & Case report & N5 \\
\hline $\begin{array}{l}\text { (A16) Differences in self-reported outcomes of open } \\
\text { prostatectomy patients and robotic prostatectomy } \\
\text { patients in an international web-based survey }\end{array}$ & 2013 & $\begin{array}{c}\text { European Journal of Oncology } \\
\text { Nursing }\end{array}$ & Literature review & N5 \\
\hline $\begin{array}{l}\text { (A17) Men's experiences of regaining urinary continence } \\
\text { following robotic-assisted laparoscopic prostatectomy } \\
\text { (RALP) for localised prostate cancer: a qualitative } \\
\text { phenomenological study }\end{array}$ & 2013 & Journal of Clinical Nursing & Descriptive exploratory & N4 \\
\hline
\end{tabular}




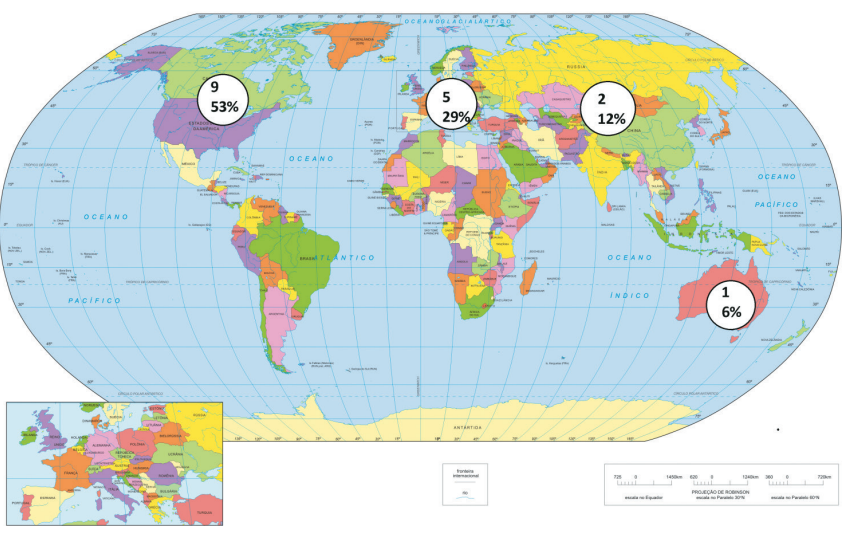

Figure 1 - Percentage of selected articles in the integrative review on nursing and robotic surgery distributed by continent, July to September, 2017

\section{DISCUSSION}

Based on the analyzed articles, it was possible to group the topic in relation to nursing practice in robotic surgeries in the three periods of the perioperative process: preoperative, intraoperative and postoperative.

\section{Preoperative}

Regarding the preoperative period, seven articles (A1, $A 2$, $A 3, A 4, A 5, A 7, A 9)$ mentioned the importance of an adequate training both for the nurse and for the entire surgical staff $f^{(5,16-21)}$. A training program for nurses allow that the professionals acquire competence and safety on the practice of care, reducing the risks for patients and contributing for positive results in nursing care ${ }^{(21)}$.

It is necessary to stress the importance in standardizing the surgical team to improve the care of patients who undergo robotic surgery ${ }^{(17-18,20)}$, providing a quality environment that ensures the safety of surgical patients ${ }^{(5,21)}$.

One of the nurses' responsibility processes is the assembly of the operating room. Articles ${ }^{(16,21)}$ highlight the importance of the preparation of the operating room according to the surgery to be performed, preparing the robotic system, in order to provide technical conditions for the adequate progress of the surgery. Thus, the nursing staff prepares equipment and provides materials and instruments according to the specific type of surgery. The necessary instruments must be available before and during the surgery ${ }^{(5)}$, and, in the day before the surgery, after the procedure of another specialty, it is necessary to install the cart, the console and vision system according to the surgery to be performed.

Even with the technological advances that foment the success of robotic surgeries, the integration with the robot still has its disadvantages, and the most cited in literature is the cost. The necessary time for the preoperative preparation of the operation room in robotic surgeries is high, elevating the total time of the surgery, thus increasing the cost ${ }^{(19)}$. Given this, any intervention that decreases the time of preparation of the surgical room can lead to shorter times and, consequently, to decreased costs.

A series of tasks is performed by the nursing staff: to verify the placement and function of pneumatic compression devices; to verify the equipment for an adequate function ${ }^{(19)}$; when preparing the operating room, to perform the conduction process of the robot safely, knowing the function of each item, to calibrate the $\mathrm{CO}_{2}$ insufflator in the correct pressure ${ }^{21}$; to ensure the filling on the pressure points, to confirm that all the connected parts of the robot are sufficiently secured before surgery ${ }^{(13)}$; to fit the robotic arms, understand the anatomical relations, memorize the steps of the operation ${ }^{(22)}$.

Another aspect that addresses patient safety and nursing care is surgical positioning, and the authors show the importance in correctly positioning the patient ${ }^{(13,18,21-22)}$. A clean assessment of anatomy, guidelines, benchmarks and anatomical variations is imperative to work in synergy with the surgeon of the console and avoid positioning injury in the patient ${ }^{(22)}$.

\section{Transoperative/Intraoperative}

Eleven articles approached robotic surgery in the trans/intraoperative period ( $A 3, A 4, A 5, A 6, A 8, A 9, A 10, A 11, A 12, A 13$ and $A 15)$. The robot-assisted surgery continues to grow in popularity worldwide ${ }^{(21)}$.

According to articles A5, A10, A11 and A15, in the intraoperative period, the nurse is responsible for guiding the robotic device for the cart of the patient, performed under the guidance of the surgeon $^{(13,20,22-23)}$. The setting and preparation of the robot for surgery includes the connection of all necessary pieces, such as sterile wrappings and necessary connectors, as well as the calibration process ${ }^{(23)}$.

Aiming at patient safety in robotic surgeries, it is important to use the checklist to reduce errors. Long robotic surgeries are associated to increased risks for patients, and the extended time during the surgery increases the risk of the patient for position-related complications and other adverse events, so that it is necessary to use and standardize a surgical checklist to improve patient safety and quality of care ${ }^{(24)}$.

Articles A5, A6 and A9 address the need for surgical counting of gauzes, compresses and instruments in order to maintain surgical safety by preventing inadvertent retention of compresses or instruments in surgical wounds $\mathrm{s}^{(19,21,24)}$.

An important aspect mentioned (A8, A9 and A13) is the efficient flow inside the operating room, as this is crucial for patient safety ${ }^{(21,25-26)}$. Evidence-based studies are necessary to face modern challenges related to equipment that increase access, workflow efficiency and patient safety ${ }^{(26)}$.

Regarding the prepare of the nursing staff to convert a robotic surgery to an open surgery, there are no standardized protocols, therefore, possible traps and mistakes during the conversion might occur; however, they have never been described. Articles A8 and A15 described the importance of the robotic surgery team to be prepared to face a conversion to open surgery, although this is a rare event. The biggest mistakes during this process are in the conflict of space and in the lack of protocol with a sequence of tasks. To adequate these conversions, repeated simulations, increased leadership, delimitation of the roles of each member of the team and reorganization of the surgical room are necessary ${ }^{(25)}$. It is important that each staff member know their role for a possible emergency and the responsibility of each one in robotic surgeries(21).

\section{Postoperative}

Only four articles (A3, A4, A16 and A17) approached the postoperative period ${ }^{(5,18,27-28)}$. In it, the nurse must be attentive to 
the needs of each patient, knowing the surgery to which he/she underwent and possible alterations to prevent complications, so, the nurse working in the postoperative stage must have knowledge and qualified skills for the different demands and complexities of the patients. It is also part of the nurse's role to provide information and support to the patient, especially when it comes to robotic surgeries, because the patient may not be familiar with this new technology and create expectations that may end up frustrated ${ }^{(27)}$. Studies demonstrate the importance of providing guidance to patients after surgery, providing information regarding postoperative care ${ }^{(5,27-28)}$.

New technologies and the search for evidence that support the practice of care in robotic surgeries make it necessary that nurses engage in research on this topic, seeking knowledge that may be disseminated and used by other nurses.

\section{Limitations of the study}

We identify as limitation of this study the low level of evidence of the selected articles. In the search on the databases, the absence of Brazilian articles was observed, which may be related to the short time of implementation of this technology in Brazil, which is less than 10 years. Also, there were no articles that approached the research topic in a Latin American or African country, possibly because they are underdeveloped or developing countries and do not have the economic resources to purchase and maintain this technology.

\section{Contributions to the field of nursing and health care}

This research brings relevant information on the nursing staff practice in robotic surgeries, identifying the role of the nurse in the three stages of the perioperative period. In light of the contemporaneity of this topic with few Brazilian publications in the Nursing area, this study aims to subsidize the practice of Brazilian professionals in the care of surgical patients submitted to robotic procedures.

\section{FINAL CONSIDERATIONS}

17 articles that met the inclusion criteria, classified with level of evidence 4 and 5, were included in this study. With this study, it was possible to know the scientific production on the nursing practice in robotic surgeries and to identify the role of the nurse in the pre, trans/intra and postoperative periods. It was evidenced that the nursing performance in this type of surgery is similar to what occurs in major surgeries, with greater concern in the positioning of the patient, requiring the nurse's participation and specific knowledge of both the positioning and the configuration and preparation of the robot. Most articles emphasize the importance of patient safety.

It was possible to notice the scarcity of studies that address the perceptions of the nurse and the role of the surgeon and in the surgical technique itself.

This study indicates the need for new Brazilian studies focused on the definition and design of the role of the nurse in robotic surgeries.

\section{REFERENCES}

1. Martins FZ, Dall'Agnoll CM. Surgical center: challenges and strategies for nurses in managerial activities. Rev Gaúcha Enferm [Internet]. 2016 [cited 2018 May 19];37(4):e56945. Available from: http://dx.doi.org/10.1590/1983-1447.2016.04.56945

2. Silva DC, Alvim NAT. [Surgical Center environment and its elements: implications for nursing care]. Rev Bras Enferm [Internet]. 2010 [cited 2018 May 19];63(3):427-34. Available from: http://dx.doi.org/10.1590/S0034-71672010000300013 Portuguese.

3. Piccoli C, Galvão CM. [Perioperative nursing: identification of the nursing diagnosis infection risk based on levine's conceptual model]. Rev Lat Am Enfermagem [Internet]. 2001 [cited 2018 Jun 24];9(4):37-43. Available from: http://dx.doi.org/10.1590/S0104-11692001000400007 Portuguese.

4. Santos FK, Silva MVG, Gomes AMT. Understanding the forms of care of nurses in the operating room: a construction based on the grounded theory method. Text Context Nursing [Internet]. 2014 [cited 2019 Jan 24];23(3):696-703. Available from: http://dx.doi. org/10.1590/0104-07072014001140013

5. Ulmer B. Best practices for minimally invasive procedures. AORN J [Internet]. 2010 [cited 2019 Mar 14];91(5):558-75. Available from: http:// dx.doi.org/10.1016/j.aorn.2009.12.028

6. Szold A, Bergamaschi R, Broeders I, Dankelman J, Forgione A, Lango T, et al. European association of endoscopic surgeons (EAES) consensus statement on the use of robotics in general surgery. Surg Endosc [Internet]. 2015 [cited 2019 Mar 14];29(2):253-88. Available from: http:// dx.doi.org/10.1007/s00464-014-3916-9

7. Darzi SA, Munz Y. The impact of minimally invasive surgical techniques. Annu Rev Med [Internet]. 2004 [cited 2019 Mar 14];55:223-37. Available from: http://dx.doi.org/10.1146/annurev.med.55.091902.105248

8. Gaia G, Holloway RW, Santoro LMS, Ahmad S, Di Silverio E, Spinillo A. Robotic-assisted hysterectomy for endometrial cancer compared with traditional laparoscopic and laparotomy approaches: a systematic review. Obstet Gynecol [Internet]. 2010 [cited 2019 Mar 14];116(6):142231. Available from: http://dx.doi.org/10.1097/AOG.0b013e3181f74153

9. Teljeur C, O'Neill M, Moran PS, Harrington P, Flattery M, Murphy L, et al. Economic evaluation of robot-assisted hysterectomy: a cost-minimisation analysis. BJOG [Internet]. 2014 [cited 2019 Mar 14];121(12):1546-53. Available from: http://dx.doi. org/10.1111/1471-0528.12836

10. Lee SJ, Calderon B, Gardner GJ, Mays A, Nolan S, Sonoda Y, et al. The feasibility and safety of same-day discharge after robotic-assisted hysterectomy alone or with other procedures for benign and malignant indications. Gynecol Oncol [Internet]. 2014 [cited 2019 Mar 
14];133(3):552-5. Available from: http://dx.doi.org/10.1016/j.ygyno.2014.04.006

11. Sousa CS, Gonçalves MC, Lima AM, Turrini RNT. Advances in the role of surgical center nurses. J Nurs UFPE [Internet] 2013 [cited 2018 May 19];10(7):6288-93. Available from: https://doi.org/10.5205/1981-8963-v7i10a12268p6288-6293-2013

12. Madureira DMF. Robotic surgery. A reality among us. Rev Col Bras Cir [Internet]. 2015 [cited 2018 May 19];42(5):281-2. Available from: http:// dx.doi.org/10.1590/0100-69912015005002

13. Kang MJ, De Gagne JC, Kang HS. Perioperative nurses' work experience with robotic surgery: a focus group study. Comput Inform Nurs [Internet]. 2016 [cited 2019 Mar 14];34(4):152-8. Available from: http://dx.doi.org/10.1097/CIN.0000000000000224

14. Mendes KDS, Silveira RCCP, Galvão CM. [Integrative literature review: a research method to incorporate evidence in health care and nursing]. Texto Contexto Enferm [Internet]. 2008 [cited 2018 June 22];17(4):758-64. Available from: http://dx.doi.org/10.1590/ S0104-07072008000400018 Portuguese.

15. Institute Joanna Briggs. New JBI levels of evidence: developed by Joanna Briggs Institute Levels of Evidence and Grades of Recommendation Working Party [Internet]. October 2013 [cited 2018 May 19]. Available from: https://bit.ly/1 KbXrOR

16. Oshiro EO, Carrasco AR, Sierra JM, Martínez CP, Romo IG, Sopelana FR, et al. [Multidisciplinary development of robotic surgery in a university tertiary hospital: organization and outcomes]. Cir Esp [Internet]. 2010 [cited 2019 Mar 14];87(2):95-100. Available from: doi:10.1016/j. ciresp.2009.10.008 Spanish.

17. Sananes N, Garbin O, Hummel M, Youssef C, Vizitiu R, Lemaho D, et al. Setting up robotic surgery in gynaecology: the experience of the strasbourg teaching hospital. J Robot Surg [Internet]. 2011 [cited 2019 Mar 14];5(2):133-6. Available from: http://dx.doi.org/10.1007/ s11701-010-0231-x

18. Minnillo BJ, Cruz JAS, Sayao RH, Passerotti CC, Houck CS, Meier PM. Long-term experience and outcomes of robotic assisted laparoscopic pyeloplasty in children and young adults. J Urol [Internet]. 2011 [cited 2019 Mar 14];185(4):1455-60. Available from: http://dx.doi. org/10.3410/f.9899957.10611055

19. De Lambert G, Fourcade L, Centi J, Fredon F, Braik K, Szwarc C, et al. How to successfully implement a robotic pediatric surgery program: lessons learned after 96 procedures. Surg Endosc [Internet]. 2013 [cited 2019 Mar 14];27(6):2137-44. Available from: http://dx.doi. org/10.1007/s00464-012-2729-y

20. Yaffee DW, Loulmet DF, Kelly LA, Ward AF, Ursomanno PA, Rabinovich AE, et al. Can the learning curve of totally endoscopic robotic mitral valve repair be short-circuited? Innovations [Internet]. 2014 [cited 2019 Mar 14];9(1):43-8. Available from: http://dx.doi.org/10.1097/ IMI.0000000000000039

21. Sarmanian JD. Robot-assisted thoracic surgery (RATS): perioperative nursing professional development program. AORN J [Internet]. 2015 [cited 2019 Mar 14];102(3):241-53. Available from: http://dx.doi.org/10.1016/j.aorn.2015.06.013

22. Yuh B. The bedside assistant in robotic surgery: keys to success. Urol Nurs [Internet]. 2013 [cited 2019 Mar 14];33(1):29-32. Available from: http://dx.doi.org/10.7257/1053-816X.2013.33.1.29

23. Guo F, Zhang C, Wang H, Sheng X, Xiao L, Sun YH, et al. Application of a laser-guided docking system in robot-assisted urologic surgery. Int J Med Robot [Internet]. 2016 [cited 2019 Mar 14];12(3):524-7. Available from: http://dx.doi.org/10.1002/rcs.1678

24. Song JB, Vemana G, Mobley JM, Bhayani SB. The second "time-out": a surgical safety checklist for lengthy robotic surgeries. Patient Saf Surg [Internet]. 2013 [cited 2019 Mar 14];7(1):19. Available from: http://dx.doi.org/10.1186/1754-9493-7-19

25. Zattoni F, Guttilla A, Crestani A, De Gobbi A, Cattaneo F, Moschini M, et al. The value of open conversion simulations during robot-assisted radical prostatectomy: implications for robotic training curricula. J Endourol [Internet]. 2015 [cited 2019 Jan 28];29(11):1282-8. Available from: http://dx.doi.org/10.1089/end.2015.0435

26. Ahmad N, Hussein AA, Cavuoto L, Sharif M, Allers JC, Hinata N, et al. Ambulatory movements, team dynamics and interactions during robotassisted surgery. BJU Int [Internet]. 2016 [cited 2019 Mar 14];118(1):132-9. Available from: http://dx.doi.org/10.1111/bju.13426

27. O'Shaughnessy PK, Laws TA, Pinnock C, Moul JW, Esterman A. Differences in self-reported outcomes of open prostatectomy patients and robotics prostatectomy patients in an international web-based survey. Eur J Oncol Nurs [Internet]. 2013 [cited 2019 Mar 14];17(6):775-80. Available from: http://dx.doi.org/10.1016/j.ejon.2013.03.010

28. Waller J, Pattison N. Men's experiences of regaining urinary continence following robotic-assisted laparoscopic prostatectomy (RALP) for localized prostate cancer: a qualitative phenomenological study. J Clin Nurs [Internet]. 2013 [cited 2019 Mar 14];22(3-4):368-78. Available from: http://dx.doi.org/10.1111/jocn.12082 